\title{
The performance of plant species in removing nutrients from stormwater in biofiltration systems in Cape Town
}

\author{
SG Milandri ${ }^{1 *}$, KJ Winter $^{1}$, SBM Chimphango ${ }^{2}$, NP Armitage ${ }^{3}$, DN Mbui ${ }^{4}$, GE Jackson ${ }^{4}$ and V Liebau ${ }^{1}$ \\ ${ }^{1}$ Department of Environmental and Geographical Sciences, University of Cape Town, Private Bag, Rondebosch 7701, South Africa \\ ${ }^{2}$ Department of Botany, University of Cape Town, Private Bag, Rondebosch 7701, South Africa \\ ${ }^{3}$ Department of Civil Engineering, University of Cape Town, Private Bag, Rondebosch 7701, South Africa \\ ${ }^{4}$ Department of Chemistry, University of Cape Town, Private Bag, Rondebosch 7701, South Africa
}

\begin{abstract}
In 2009, the City of Cape Town (CoCT) adopted a stormwater policy which mandates that new and existing developments should reduce the concentration of phosphorus and suspended solids in stormwater runoff by $45 \%$ and $80 \%$, respectively, but offered no explicit guidance about how these water quality targets might be achieved. This study aims to contribute to the limited knowledge that exists about the performance of local plant species to treat stormwater. A large nursery-based study was conducted to investigate the performance of 9 locally-occurring plant species to remove orthophosphate $\left(\mathrm{PO}_{4}^{-3}\right)$, ammonia $\left(\mathrm{NH}_{3}\right)$ and nitrate $\left(\mathrm{NO}_{3}^{-}\right)$found in urban stormwater. Synthetic stormwater was applied to each species as well as a control consisting only of soil (Malmesbury shale). The discharge was collected from a drainage pipe at the base of each of the 150 containers. The results show that all species (excluding Ficinia) reduced the average concentrations of $\mathrm{PO}_{4}^{-3}$ by $81 \%$ and $\mathrm{NH}_{3}$ by $90 \%$. By contrast, $\mathrm{NO}_{3}{ }^{-}$was reduced by an average of $69 \%$ (excluding by Elegia and Phragmites) with 8 of the 9 species removing significantly more than the control. The species that performed well for all three nutrients include Agapanthus and turf grasses, Stenotaphrum and Pennisetum. The results of the study highlight three important factors in the design of biofilters: that a substantial proportion of nutrients can be captured or absorbed by plants; that the soil medium is an important factor in the removal of $\mathrm{PO}_{4}^{-3}$ and $\mathrm{NH}_{3}$; and that plant choice is essential in the removal of $\mathrm{NO}_{3}^{-}$. Future research should test plant species in both the laboratory and field settings, and should include additional contaminants such as household detergents, heavy metals and bacteria.
\end{abstract}

Keywords: Biofilter, sustainable drainage systems (SuDS), stormwater treatment, nutrient removal

\section{Introduction}

In 2009, the City of Cape Town (CoCT) adopted a stormwater policy with the aim of reducing the pollution load in stormwater runoff. Indirectly, the policy also intended to address mounting concerns about the general deterioration of urban green spaces and the loss of biodiversity (CoCT, 2009). The policy establishes water quality targets for all new and existing developments that are situated in catchments with sensitive freshwater systems, and includes the targets of reducing phosphorus and suspended solids by $45 \%$ and $80 \%$, respectively (CoCT, 2009). The policy is consistent with the concept and principles of sustainable drainage systems (SuDS), which typically include the use of a treatment train of vegetated filters (i.e. biofilters) to reduce the rate of surface runoff and enhance the natural processes of infiltration, sedimentation and biological uptake of nutrients prior to being released into freshwater systems (Ghani, 2008; Melbourne Water, 2005; Villarreal et al., 2004; EA, 2003; Bottcher et al., 1995; Livingston, 1992). SuDS biofilters can vary in size, location and appearance (Hatt et al., 2009), and include technologies such as vegetated filterstrips, roadside swales, green roofs, retention and detention ponds, and natural and artificial wetlands (Australian WSUD Guidelines, 2007; CIRIA, 2007; Woods-Ballard et al., 2007; Knox City Council, 2002).

\footnotetext{
* To whom all correspondence should be addressed.

+2784 521-6783; e-mail: smilandri@gmail.com

Received 26 October 2011; accepted in revised form 25 September 2012.
}

Research has demonstrated that biofilters are able to substantially reduce the concentration of suspended solids (90-96\%), heavy metals (>90\%) and phosphorus (70-94\%) (Bratieres et al., 2008; Fletcher et al., 2007; Henderson et al., 2007; Davis et al., 2001, 2003, 2006). However, total nitrogen removal varies considerably $(15-65 \%)$ due to the leaching of nitrate $\left(\mathrm{NO}_{3}^{-}\right)$from biofiltration systems (Bratieres et al., 2008). Bratieres et al. (2008) emphasized the importance of treatment train design, as the uptake of each pollutant or nutrient is influenced by a number of factors. For example, if a reduction in total nitrogen is the primary objective, then the components of the biofilter, that is the choice of plant species and soil, and the layout of each treatment train element, must be designed to prevent factors such as the leaching of nitrates (Davis et al., 2006). However, in the case of total phosphorus and suspended solids, biofilter systems consistently removed at least $80 \%$ of both pollutants irrespective of the biofilter design (Bratieres et al., 2008; Fletcher et al., 2007; Henderson et al., 2007). This highlights the role of the soil media in removing certain pollutants, although various factors must be taken into account. For example, Davis et al., (2001) found that organic matter improved the extent to which heavy metals were removed, but also encouraged the leaching of nutrients (Hsieh and Davis, $2005 \mathrm{a}, \mathrm{b})$. In addition, an increase in the soil depth improved the removal of phosphorus, but increased the leaching of nitrate (Davis et al., 2006). However, plant choice is also important for targeting specific pollutants. For example, Read et al. (2008) found that while Juncus species removed nutrients, they were unable to remove heavy metals such as lead. Bratieres et al. (2008) found that only 2 of the 5 plant species tested (Carex and Melaleuca) were capable of removing more than $70 \%$ of 
total nitrogen; and Henderson et al. (2007) found that vegetated columns retained $63-77 \%$ of nitrogen, while non-vegetated columns leached nitrogen. As such, constructed biofilters should include a mixture of plant species that target specific pollutants (Revitt et al., 2004), but must also be able to survive stressful situations such as drought or flood (Bratieres et al., 2008).

The CoCT is currently facing a number of challenges in the implementation of the SuDS treatment train. Firstly, although international research has demonstrated that SuDS biofilters can reduce runoff volumes and improve quality, it has been difficult to quantify the extent to which these technologies meet the water quality targets in conditions likely to be found in the CoCT. Most research has been conducted in developed countries where heavy metals are often the primary stormwater pollutants. In addition, the performance of vegetation in removing nutrients varies between plant species (Read et al., 2008) and is affected by local climatic conditions (Bratieres et al., 2008), all of which suggests that knowledge about the performance of locally-occurring species is an imperative in establishing the performance of biofilters. This study seeks to clarify at least these uncertainties about the performance of biofilters by establishing empirical evidence from a nursery-based study to investigate the individual performance of 9 locally-occurring plant species to treat stormwater for the removal of orthophosphate $\left(\mathrm{PO}_{4}^{-3}\right)$, ammonia $\left(\mathrm{NH}_{3}\right)$ and nitrate $\left(\mathrm{NO}_{3}^{-}\right)$, and thereby to reduce overall nutrient loads. The study had 2 primary objectives:

- to assess the ability of each plant species to remove nutrients from stormwater; and

- to assess how plant growth responds to the nutrients in stormwater.

\section{Materials and methods}

\section{Experimental setup}

The experiment was conducted in a glasshouse at the University of Cape Town between August 2009 and September 2010, and included 9 plant species of varying physical growthhabits (e.g. turf-grass, succulent-perennial and reed) and a soil-only control. The choice of plant species included 9 rapidly-maturing species which were suited to various components of the SuDS treatment train (e.g. filter-strips, swales and wetlands), but considered dryland and wetland plant categories that are typical of conditions in constructed treatment trains (Table 1). These included 5 species that are found in dryland environments and can tolerate temporary inundation, and
4 wetland species that typically occur in areas that are exposed to seasonal or long-term inundation. All these selected species are indigenous to South Africa (except Pennisetum) and are used widely in the CoCT by municipalities, landscaping companies and homeowners due to their drought resistant and ornamental value (Bardsley and Edwards-Jones, 2007; Brown, et al. 1998; Duncan, 1998; Rumball, 1991). Although Pennisetum is classified as invasive (Cilliers and Bredenkamp, 2000), it is widely used in the $\mathrm{CoCT}$ as it is able to tolerate varying moisture and salinity levels (Muscolo et al., 2003).

A total of 150 containers were constructed from $150 \mathrm{~mm}$ x $500 \mathrm{~mm}$ polyvinyl chloride (PVC) pipes, each with a 22 $\mathrm{mm}$ (diameter) perforated drainage pipe that protruded from the sealed base of each container so that the outflow could be discharged into collection containers placed immediately below each container (Figs 1 and 2). In August 2009, each species was individually planted into 30 containers of weathered Malmesbury shale (sandy soil) (infiltration rate: $7 \mathrm{m \ell} / \mathrm{s}$ ), except the turf-grasses (Pennisetum and Stenotaphrum), which were planted with 5 plants per container. A number of drainage layers were placed below the Malmesbury shale, comprising of coarse silica sand and gravel to prevent the loss of soil media and clogging of the drainage pipe. The soil column was filled

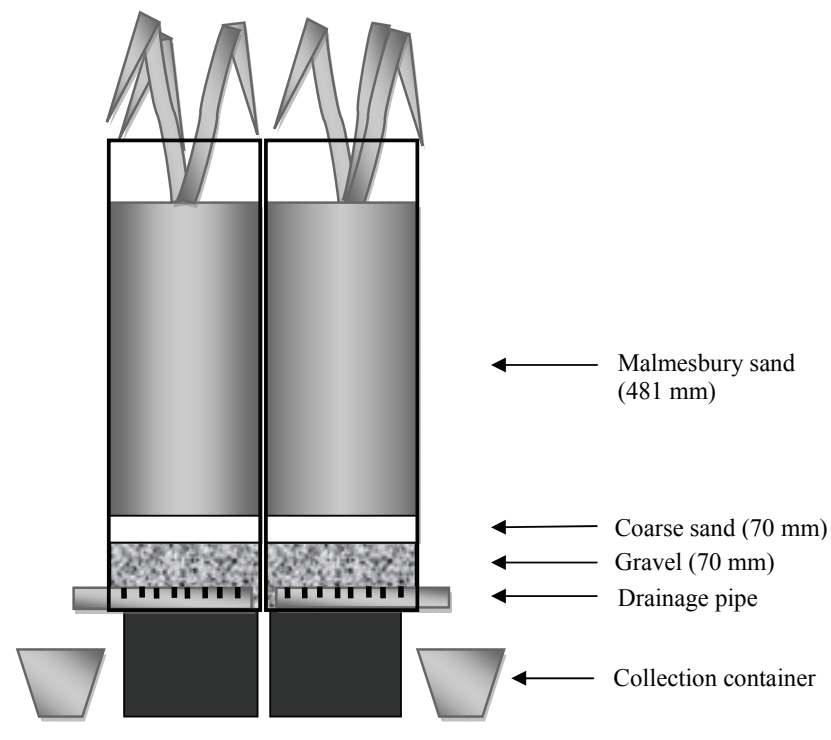

Figure 1

Experimental setup (cross-section of 2 containers)

\begin{tabular}{|c|c|c|c|c|}
\hline \multicolumn{5}{|c|}{$\begin{array}{c}\text { Table } 1 \\
\text { List of plant species within growth habitats, and physical plant measurements taken for each species } \\
\text { (indicated with X) }\end{array}$} \\
\hline \multicolumn{2}{|l|}{ Genus and species } & \multicolumn{3}{|c|}{ Physical Plant Measurements } \\
\hline Dryland plants: & & No. of stalks & No. of leaves & Length of longest stalk/leaf \\
\hline Agapanthus praecox & Common agapanthus & & $\mathrm{X}$ & $\mathrm{X}$ \\
\hline Carpobrotus edulis & Sour fig & & & \\
\hline Elegia tectorum & Thatching reed & & & $\mathrm{X}$ \\
\hline Pennisetum clandestinum & Kikuyu grass & & & $\mathrm{X}$ \\
\hline Stenotaphrum secundatum & Buffalo grass & & & $\mathrm{X}$ \\
\hline \multicolumn{5}{|l|}{ Wetland plants: } \\
\hline Zantedeschia aethiopica & Arum lily & $\mathrm{X}$ & $\mathrm{X}$ & $\mathrm{X}$ \\
\hline Ficinia nodosa & Knobby club-rush & & $\mathrm{X}$ & $\mathrm{X}$ \\
\hline Phragmites australis & Common reed & $\mathrm{X}$ & $\mathrm{X}$ & $\mathrm{X}$ \\
\hline Typha capensis & Bulrush & $\mathrm{X}$ & $\mathrm{X}$ & $\mathrm{X}$ \\
\hline
\end{tabular}




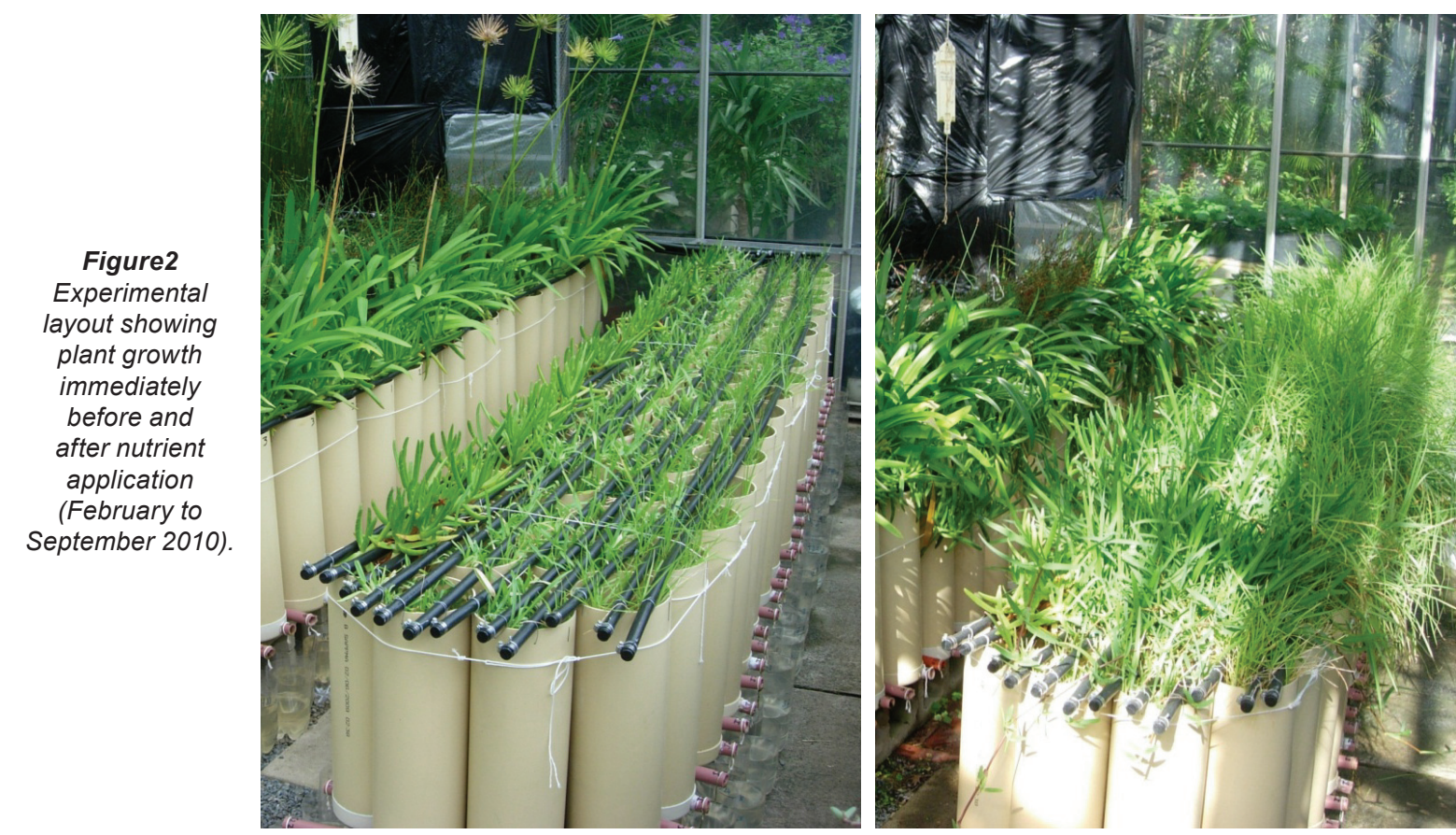

to approximately $5 \mathrm{~cm}$ below the rim of each container for the collection and retention of water during irrigation. All plant species were irrigated with tap water from August 2009 until February 2010 to reach a mature stage.

An automated irrigation system was installed to ensure a regular irrigation regime (every 3 days). It consisted of a computer (Irritrol ${ }^{\circledR}$ Junior ${ }^{\mathrm{TM}}$ MAX) controlling 3 relays $(24 \mathrm{~V}$ $\mathrm{A} / \mathrm{C}$ ), and which was programmed to control the timing of the 3 pumps (Foras ${ }^{\circledR}$ PE-50M). Each pump transferred the water from a $500 \ell$ water tank using $15 \mathrm{~mm}$ irrigation pipes attached to 100 containers fitted with drippers $(4 \ell / h)$. Each tank supplied water to 1 of 3 different treatments, namely Tap Water, Synthetic Stormwater 1 (S1) or Stormwater $2(\mathrm{~S} 2)( \pm \mathrm{S} 1$ x 2$)$ (Table 2), with each being applied to a third of all plant species, and the control, from March to September 2010. Thus each species, and the soil-only control, had 10 replicates per treatment. The tanks containing S1 and S2 were each fitted with a submersible pump that continually circulated the nutrient solution to prevent stagnation and ensure the dispersion of nutrients. In addition, an in-line electric valve $(24 \mathrm{~V} \mathrm{~A} / \mathrm{C})$ was installed to turn on with each pump to prevent the loss of water from the tanks via siphoning. Each tank was fitted with an external clear pipe with $100 \ell$ levels marked on the tank between 0 and $400 \ell$, to assist with the re-filling of the tanks.

\section{Experimental procedure}

The timing of the irrigation, set at an interval of 3 days, was based on rainfall during Cape Town's 6 wettest months (SAWS, 2011). However, to standardise the irrigation volume, each container was irrigated with $1 \ell$ of water per dosing to deliver a sufficient volume of water for the water sample analysis. Stormwater quality data from 3 sites in the CoCT were used as a guide for the mixture of 'synthetic stormwater' at 2 concentration levels (Table 2 ) based on the $75^{\text {th }}$ percentile value of the selected nutrients. This enabled the use of a fairly representative composition of nutrients in local stormwater and also ensured standardised nutrient concentrations in irrigation water. The nutrient solutions (S1 and S2), formulated to dilute

\begin{tabular}{|l|c|c|c|}
\hline \multicolumn{4}{|c|}{ Table 2 } \\
Stormwater solution (S1 and S2) \\
\hline Nutrient & $\begin{array}{c}\text { Chemical } \\
\text { source }\end{array}$ & $\mathbf{S 1}$ (mg/e) & $\mathbf{S 2}(\mathbf{m g} / \mathbf{\ell})$ \\
\hline Orthophosphate & $\mathrm{PO}_{4}^{-3}$ & 1.470 & 2.620 \\
\hline Ammonia & $\mathrm{NH}_{3}$ & 0.567 & 2.202 \\
\hline Nitrate & $\mathrm{NO}_{3}^{-}$ & 3.117 & 5.983 \\
\hline
\end{tabular}

into $400 \ell$, were added to the respective tanks when they were refilled every 8 days.

Efforts were made to add suspended solids to the synthetic stormwater. Clay was collected in Hout Bay, sieved through a $125 \mu \mathrm{m}$ sieve and added to S1 and S2. However, despite the fine particle size and use of submersible pumps intended to maintain suspension, the suspended particles gradually settled causing a rapid drop in concentration. The organic matter also fermented in the tanks. Consequently the use of sediment was discontinued, and only nutrients were included in the stormwater solution.

\section{Assessment of pollutant removal}

Water samples were collected on 3 occasions during the study. This began on 13 July 2010 and was repeated every 3 weeks. Water samples $(250 \mathrm{~m} \ell)$ were taken in new plastic collection containers from each tank (inflow) and from the outflow of each container (per treatment per species), and then transferred into labelled sample bottles for transport to the laboratory. The collection containers and sample bottles were initially rinsed in distilled water, but this was later changed to tap water when it was found that this had no influence on the analysis of water samples. Water samples were not filtered as there was no settling in the sample bottles. A $10 \mathrm{~m} \ell$ water sample was extracted from each sample bottle and then tested in the Water Analysis Laboratory at the University of Cape Town for orthophosphate $\left(\mathrm{PO}_{4}^{-3}\right)$, ammonia $\left(\mathrm{NH}_{3}\right)$ and nitrate $\left(\mathrm{NO}_{3}^{-}\right)$. All water samples were analysed using a HACH DR $2700^{\mathrm{TM}}$ Portable Spectrophotometer (wavelength accuracy: $\pm 1.5 \mathrm{~nm}$; wavelength range: 400 to $900 \mathrm{~nm}$ ). 
Unless noted, all of the results are presented as the total reduction in concentration determined by subtracting the water sample concentration from the inflow concentration. Although the analysis of percentage removal could be faulty if stormwater were sourced from a field-based source, due to fluctuating inflow concentrations (Bratieres et al., 2008), the percentage removal is comparable in this study as inflow concentrations could not fluctuate as they were premixed to standardised levels.

\section{Measurement of plant growth}

From February to August 2010, a variety of physical plantgrowth parameters were recorded on a monthly basis, to analyse the relationship between nutrient concentration and plant growth. The analysis included tallies of the number of stems, number of leaves and length of longest stem or leaf (Table 1). However, the number and choice of measurements depended on the physical characteristics of each plant species. For example, it was possible to measure these variables for Phragmites, but impractical for the turf-grass Stenotaphrum. In addition, the growth of Zantedeschia was complicated to monitor because of natural cycles of dying back and re-growing (especially during the summer months).

\section{Analysis of pollutant removal and plant growth}

A 2-way analysis of variance (ANOVA) was used to assess both the effect of species and treatment on nutrient removal and the physical growth-response of selected plant species. The nutrient removal data were transformed by arcsine square root transformation (Sokal and Rohlf, 1995), and plant growth data were $\log$ transformed where appropriate. Duncan's multiple range technique was used to separate the averages that were significantly different at $P \leq 0.05$.

\section{Results}

\section{Nutrient removal: Dryland and wetland species}

Initially it was presumed that dryland and wetland plants would vary in their ability to remove nutrients because of their differences in moisture needs (e.g. wetland vs. terrestrial). However, a nested ANOVA design showed that there was no significant difference between them (Table 3 ) and therefore all of the plants were analysed together. A nested ANOVA was chosen because the species in these two groups were different and this negated the use of a normal ANOVA.

\section{Orthophosphate $\left(\mathrm{PO}_{4}^{-3}\right)$}

The 6 best-performing species (Agapanthus, Pennisetum, Stenotaphrum, Zantedeschia, Phragmites and Typha) were up to $16 \%$ more effective than the soil-only control and reduced the outflow concentration of $\mathrm{PO}_{4}^{-3}$ by a total of $80-95 \%$ for the same stormwater treatments (Fig. 3). These results were consistent with the findings of other studies (Bratieres et al., 2008; Read et al., 2008; Fletcher et al., 2007; Henderson et al., 2007; Davis et al., 2001, 2003, 2006), and, importantly, exceeded the CoCT's recommendation of a $45 \%$ reduction in phosphorus, assuming that $\mathrm{PO}_{4}^{-3}$ was a suitable proxy for total phosphorus (CoCT, 2009). However, only one species for S1 (Phragmites), and four species for S2 (Agapanthus, Pennisetum, Stenotaphrum

\begin{tabular}{|l|l|l|l|}
\hline \multicolumn{4}{|c|}{ Table 3 } \\
$\begin{array}{l}\text { Plant form: wetland vs. dryland species showing degrees } \\
\text { of freedom using nested ANOVA (ns = not significant) }\end{array}$ \\
\hline Plant form & F-statistics \\
\hline $\begin{array}{l}\text { Wetland and dryland } \\
\text { species }\end{array}$ & Orthophosphate & Ammonia & Nitrate \\
\hline F-statistic & & $0.1 \mathrm{~ns}$ & $1.3 \mathrm{~ns}$ \\
\hline
\end{tabular}

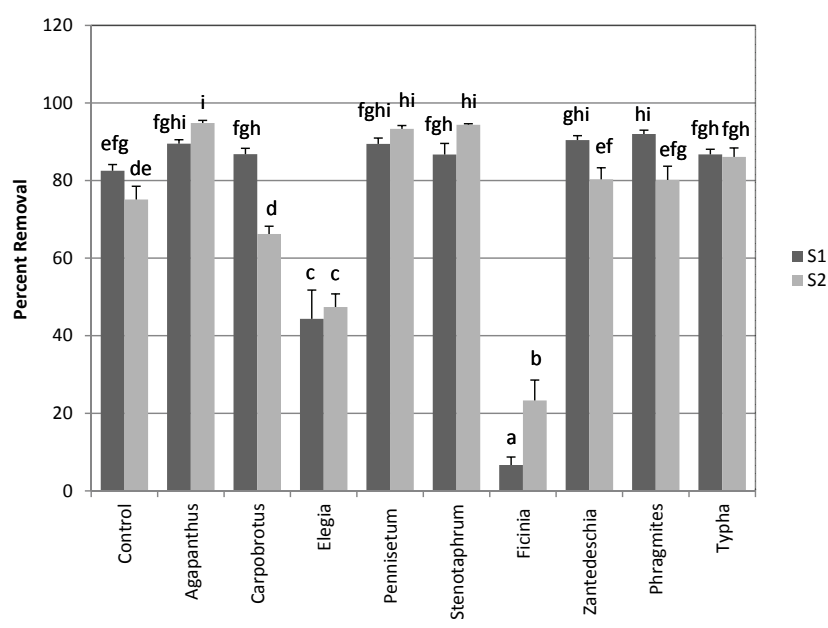

Figure 3

Per cent removal of $\mathrm{PO}_{4}^{-3}$ by all species and soil-only control. Bars are averages $\pm S E$. Bars with different letters are significantly different $(P \leq 0.001)$ from each other after analysis of variance (ANOVA) and means separated by Duncan's multiple range test.

and Typha) removed significantly more $\mathrm{PO}_{4}^{-3}$ than the control. Carpobrotus performed similarly to the control for S1, but was significantly less effective for S2, and removed only $66 \%$. The two remaining species (Elegia and Ficinia) were both significantly less effective than the control for both stormwater treatments and removed an average of $46 \%$ and $15 \%$, respectively. Although these two species removed significantly less $\mathrm{PO}_{4}^{-3}$ then the control, the presence of vegetation in a field setting could have other benefits, such as slowing the rates of flow, improving infiltration into the soil, and improving water quality.

\section{Ammonia $\left(\mathrm{NH}_{3}\right)$}

The 9 plant species reduced outflow concentrations of $\mathrm{NH}_{3}$ by $66-99 \%$ for S2 stormwater treatments (average 91\%), with only 2 species, Carpobrotus and Elegia, being less effective than the control for S1 stormwater treatment (Fig. 3). The soil-only control removed an average of $85 \%$ for the same treatments, highlighting its role as a filter in containing $\mathrm{NH}_{3}$. Similar ranges of removal were obtained in studies elsewhere (Bratieres et al., 2008; Fletcher et al., 2007; Henderson et al., 2007; Popov et al., 2006; Davis et al., 2001, 2003, 2006). In this study, the most effective species, namely the turf-grasses Pennisetum and Stenotaphrum, were significantly more effective than the control (up to $22 \%$ ) for both stormwater treatments, and reduced the outflow concentrations of $\mathrm{NH}_{3}$ by a total of $97 \%$ for S1 and $99 \%$ for S2. For the remaining species only Agapanthus, Ficinia, Zantedeschia, Phragmites and Typha performed significantly better than the control for S1 (by 15\%), while none of them performed significantly better for $\mathrm{S} 2$. Nonetheless, the plant species still removed an average of $6 \%$ more than the soil-only control, and can thus all be considered for inclusion in the design of biofilters intended to remove $\mathrm{NH}_{3}$. 


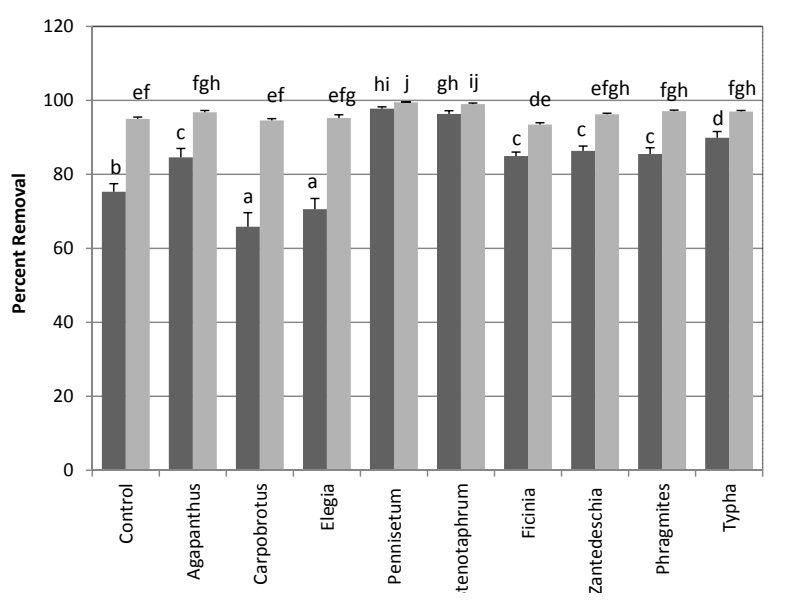

Figure 4

Per cent removal of $\mathrm{NH}$ by all species and soil-only control. $B$ ars are averages $\pm S E$. Bars with different letters are significantly different $(P \leq 0.001)$ from each other after analysis of variance (ANOVA) and means separated by Duncan's multiple range test.

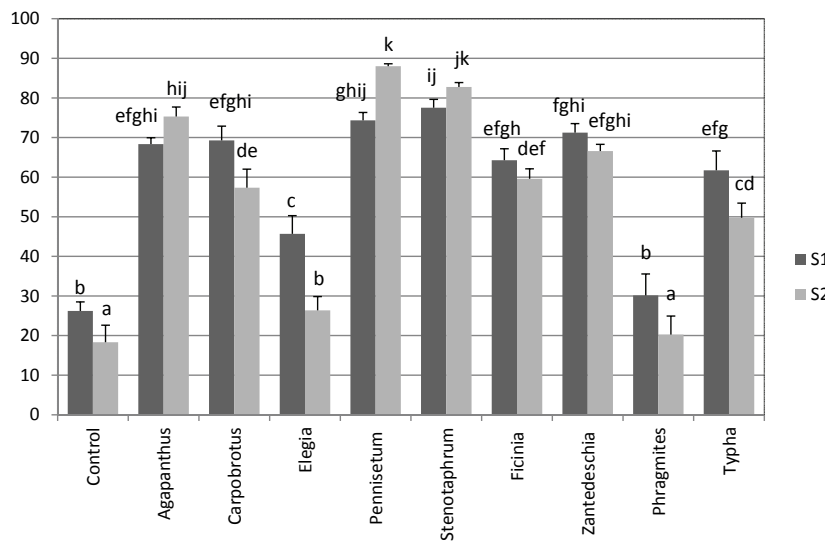

Figure 5

Per cent removal of $\mathrm{NO}_{3}{ }^{-}$by all species and soil-only control. Bars are averages \pm SE. Bars with different letters are significantly different $(P \leq 0.001)$ from each other after analysis of variance (ANOVA) and means separated by Duncan's multiple range test.

\section{Nitrate $\left(\mathrm{NO}_{3}^{-}\right)$}

In the current study, the 9 plant species reduced outflow concentrations of $\mathrm{NO}_{3}^{-}$by between 20 and $88 \%$ for both stormwater treatments (average 60\%) (Fig. 5). Eight of the species (excluding Phragmites) were observed to remove significantly more than the control, which removed just $22 \%$. The turf-grasses Pennisetum and Stenotaphrum were the two most effective species (up to $70 \%$ more than control) with a reduction in the total outflow concentrations of $76 \%$ for $\mathrm{S} 1$, and $85 \%$ for $\mathrm{S} 2$. The performance of these two species may be explained by their rapid growth rates. Agapanthus, Carpobrotus, Ficinia, Zantedeschia and Typha reduced outflow concentrations by a total of $49-75 \%$, equivalent to an improvement of $27-53 \%$ on the performance of the control. For the 2 remaining species (Elegia and Phragmites), only Elegia showed a significantly greater reduction than the control. The higher $\mathrm{NO}_{3}^{-}$removal rate in the current study may be due to the use of drip irrigation, which, unlike the

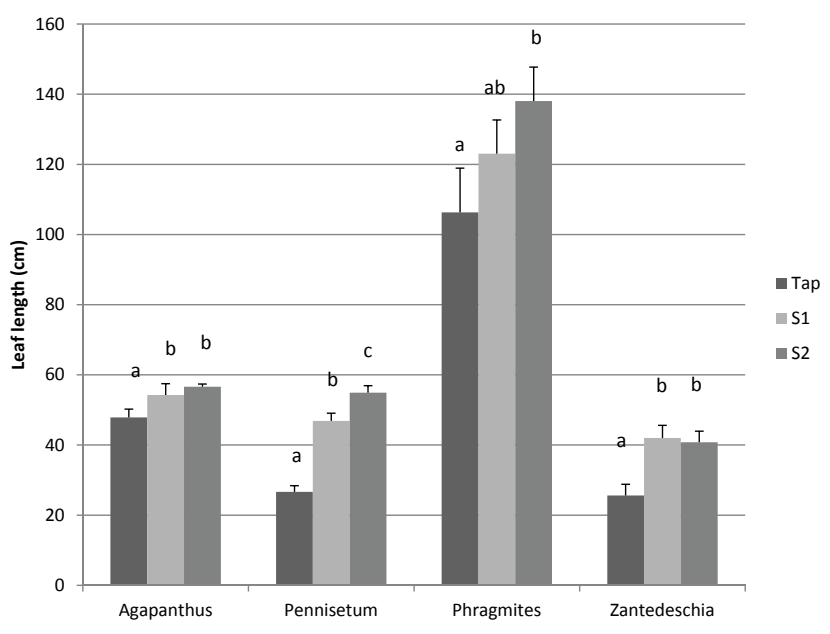

Figure 6

Length of longest leaf in response to tap water and the stormwater treatment (S1 and S2). Bars with different letters are significantly different $(P \leq 0.001)$ from each other after analysis of variance (ANOVA) and means separated by Duncan's multiple range test.

rapid irrigation used by Bratieres et al. (2008) and Read et al. (2008), would have percolated slowly through each container and allowed more time for the uptake of water and dissolved nutrients (Trowsdale and Simcock, 2010; Muscolo et al., 2003; Savchenko et al., 1997). This may also have encouraged the rapid growth-rates of selected species which occurred in response to the applied nutrients.

\section{Leaf and stem measurement}

From February 2010 a variety of physical plant-growth parameters were measured on a monthly basis until the completion of the experiment. Only the number and length of leaves showed significant increases in growth for the plants receiving S1 or S2 compared to those receiving tap water (Figs 6 and 7). The increase in growth suggests that the plants absorbed the applied nutrients in comparison to those plants that only received tap water.

The application of stormwater concentrations S1 and S2 resulted in significant increases in leaf length for several species (Fig. 6). These included 2 dryland species (Agapanthus and Pennisetum) and 2 wetland species (Phragmites and Zantedeschia). Only Pennisetum showed significant increases in leaf length in response to both stormwater treatments, with this species showing increased growth-rates in response to the application of stormwater within the first month. Agapanthus and Zantedeschia showed a similar pattern, although there was no significant difference between stormwater treatments. Phragmites showed a significant increase in leaf length but only for those plants irrigated with S2 water. These 4 species were also typically effective in removing applied nutrients, with outflow concentrations being reduced by $80-95 \%$ for $\mathrm{PO}_{4}^{-3}, 84-99 \%$ for $\mathrm{NH}_{3}$ and $66-88 \%$ for $\mathrm{NO}_{3}^{-}$(excluding Phragmites).

The application of stormwater (S1 and S2) also significantly increased the leaf number of several species (Fig. 7). These included Agapanthus and Phragmites as well as the wetland plants Ficinia and Typha. Agapanthus and Typha showed significant increases in leaf number in response to the application of both stormwater treatments (S1 and S2). 


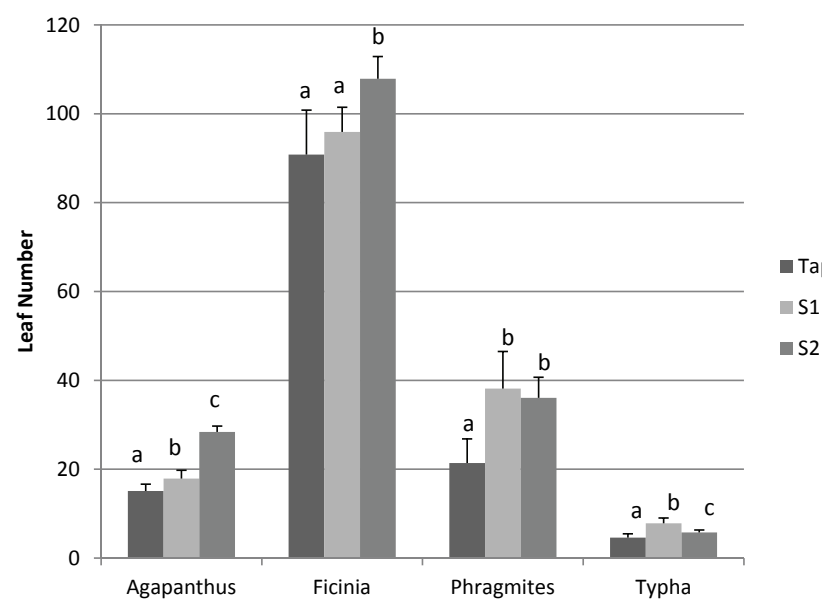

Figure 7

Differences in leaf number in response to stormwater treatment (S1 and S2). Bars with different letters are significantly different $(P \leq 0.001)$ from each other after analysis of variance (ANOVA) and means separated by Duncan's multiple range test.

However, in the case of Ficinia, the only significant increases in leaf number were found in those plants that received S2 water. Phragmites showed a significant increase in leaf number but there was no significant difference between treatments S1 and S2. These species were also typically effective in removing applied nutrients with outflow concentrations being removed by $80-94 \%$ for $\mathrm{PO}_{4}^{-3}$ (excluding Ficinia); $85-97 \%$ for $\mathrm{NH}_{3}$; and $50-75 \%$ for $\mathrm{NO}_{3}^{-}$(excluding Phragmites). However, the study did not attempt to determine which of the 3 nutrients were responsible for the increase in growth. Nonetheless, the observed relationship indicates a physical growth-response as a result of the absorption of nutrients.

\section{Discussion}

This study sought to identify the extent to which individual plant species could act as biofilters by removing $\mathrm{PO}_{4}^{-3}, \mathrm{NH}_{3}$ and $\mathrm{NO}_{3}^{-}$from a synthetic stormwater. There is potential to use these results to understand more about how plant species can be used to design SuDS treatment trains to target a selection of nutrients found in urban stormwater. Table 4 lists the selected plant species and the soil-only control in rank order according to the average values for the absorption of each nutrient. Evidence presented in Table 4 shows that Pennisetum, Stenotaphrum and Agapanthus were generally the 3 best-performing species in the removal of all 3 nutrients. These species removed at least $91 \%$ of both $\mathrm{PO}_{4}^{-3}$ and $\mathrm{NH}_{3}$, and $72 \%$ of $\mathrm{NO}_{3}^{-}$.

While plants such as Pennisetum, Stenotaphrum and Agapanthus consistently removed a large percentage of each nutrient, possibly as a result of rapid growth rates (Figs. 6 and 7), some species were effective in removing particular nutrients and not others. For example Ficinia removed only $15 \%$ of $\mathrm{PO}_{4}^{-3}$, but removed $89 \%$ and $62 \%$ of $\mathrm{NH}_{3}$ and $\mathrm{NO}_{3}^{-}$, respectively. In addition, Phragmites removed $86 \%$ of $\mathrm{PO}_{4}^{-3}$ and $91 \%$ of $\mathrm{NH}_{3}$, but only $25 \%$ of $\mathrm{NO}_{3}^{-}$. Phragmites showed significant growth-responses to the application of stormwater (Figs. 6 and 7) and a similar response was observed in the soil-only control, which removed $79 \%$ of $\mathrm{PO}_{4}^{-3}, 85 \%$ of $\mathrm{NH}_{3}$, but only $22 \%$ of $\mathrm{NO}_{3}^{-}$. Despite low $\mathrm{NO}_{3}^{-}$removal by the soil-only control, this result is better than that obtained by Henderson et al., (2007) who found that un-vegetated soil leached nitrogen.

The current results highlight the importance of including a variety of plants in SUDS design, because the plant species varied (sometimes considerably) in their removal of each nutrient, and also to enhance biodiversity in an urban environment. Even if particular plant species is not effective in removing a particular nutrient, their presence in a field setting could possibly slow rates of flow, thus encouraging infiltration into the soil. This is consistent with the finding of Bratieres et al. (2008) and Read et al. (2008), who found that plant species varied in their pollutant-removal performance such that a spectrum of species should be included in biofilter design.

In the CoCT all of the selected species could be used in the SuDS treatment train, starting with dryland species such as Pennisetum, Stenotaphrum, and Agapanthus in filter-strips, green roofs and/or swales, and wetlands planted with configurations of Ficinia, Phragmites, Typha and Zantedeschia. Thus nutrient-rich stormwater runoff could be passed through the treatment train to gradually improve water quality to the point where it reaches an acceptable concentration before entering freshwater systems. The use of these species in combination not only makes use of their individual nutrient-removal performance, but could also encourage the inclusion of less effective species for aesthetic or biodiversity purposes.

\begin{tabular}{|c|c|c|c|}
\hline \multicolumn{4}{|c|}{$\begin{array}{c}\text { Table } 4 \\
\text { List of species and soil-only control (highlighted grey) in order of average } \\
\text { performance values (per cent removal) for each nutrient. Each value is the } \\
\text { mean percentage removal of } \mathrm{S} 1 \text { and } \mathrm{S} 2 \text {. }\end{array}$} \\
\hline Rank & $\mathrm{PO}_{4}^{-3}$ & $\mathrm{NH}_{3}$ & $\mathrm{NO}_{3}^{-}$ \\
\hline 1 & Agapanthus (92\%) & Pennisetum (99\%) & Pennisetum $(81 \%)$ \\
\hline 2 & Pennisetum $(91 \%)$ & Stenotaphrum $(98 \%)$ & Stenotaphrum (80\%) \\
\hline 3 & Stenotaphrum (91\%) & Typha $(93 \%)$ & Agapanthus (72\%) \\
\hline 4 & Phragmites $(86 \%)$ & Agapanthus (91\%) & Zantedeschia (69\%) \\
\hline 5 & Typha $(86 \%)$ & Phragmites (91\%) & Carpobrotus (63\%) \\
\hline 6 & Zantedeschia $(85 \%)$ & Zantedeschia $(91 \%)$ & Ficinia $(62 \%)$ \\
\hline 7 & Control $(79 \%)$ & Ficinia $(89 \%)$ & Typha $(56 \%)$ \\
\hline 8 & Carpobrotus (77\%) & Control $(85 \%)$ & Elegia $(36 \%)$ \\
\hline 9 & Elegia $(46 \%)$ & Elegia $(83 \%)$ & Phragmites (25\%) \\
\hline 10 & Ficinia $(15 \%)$ & Carpobrotus $(80 \%)$ & Control $(22 \%)$ \\
\hline
\end{tabular}




\section{Conclusion}

Three plant species, namely Agapanthus, Pennisetum and Stenotaphrum, absorbed over $80 \%$ of all nutrients and are thus highly recommended species for inclusion in local biofiltration systems. Although 3 species (Elegia, Ficinia and Phragmites) performed poorly for at least 1 nutrient each, the evidence shows that a variety of species should be used in the treatment train, not only to target specific nutrients prior to release of runoff into freshwater systems, but also to encourage species diversity.

The removal of $\mathrm{PO}_{4}^{-3}$ and $\mathrm{NH}_{3}$ by plant species was minimally affected by plant choice as most of the treatment occurred within the soil medium. The use of Malmesbury shale as a soil media accounted for $75-83 \%$ of $\mathrm{PO}_{4}^{-3}$ and $75-95 \%$ of $\mathrm{NH}_{3}$ removal. This is significant for the CoCT as this soil is widely available and can thus be recommended as a soil-media in biofiltration systems that target these nutrients. Although this study demonstrated that plant choice is essential for the effective removal of $\mathrm{NO}_{3}$, the soil-only control still accounted for $22 \%$ of total removal, and can thus also contribute to the total removal of this nutrient.

Further research is needed to investigate a variety of issues in both laboratory and field settings. These include pollutant-, plant- and soil-related issues. While the current study focused on the removal of $\mathrm{PO}_{4}^{-3}, \mathrm{NH}_{3}$ and $\mathrm{NO}_{3}^{-}$, additional contaminants such as household chemicals, heavy metals, pathogens and suspended solids should be tested, as well as their accumulation in soil and potential toxicity. A wider variety of plant species is also of interest in an effort to understand competition between species and the ability of these plants to tolerate climatic and site-specific stress (e.g. regular inundation, human traffic and mowing). Longer-term studies are also required to understand the impact of these issues on pollutant removal. Although Malmesbury shale was effective in removing $\mathrm{PO}_{4}^{-3}$ and $\mathrm{NH}_{3}$ in the current study, the effect of depth and type of soil on long-term pollutant removal and long-term maintenance should also be considered. Investigating these issues will guide the implementation of SuDS in the CoCT and improve the knowledge available for the development of treatment trains throughout the city.

\section{Acknowledgements}

This research was funded by the Water Research Commission (WRC) in the project entitled: Alternative technology for stormwater management (WRC Project No. K5/1826).

\section{References}

AUSTRALIAN WSUD GUIDELINES (2007) National Guidelines for Evaluating Water Sensitive Urban Design (WSUD). Brisbane, Australia.

BARDSLEY DK and EDWARDS-JONES G (2007) Invasive species policy and climate change: social perceptions of environmental change in the Mediterranean. Environ. Sci. Polic. $10230-242$.

BOTTCHER A, TREMWEL TK and CAMPBELL KL (1995) Best management practices for water quality improvement in the Lake Okeechobee Watershed. Ecol. Eng. 5 341-356.

BRATIERES K, FLETCHER TD, DELETIC A and ZINGER Y (2008) Nutrient and sediment removal by stormwater biofilters: A largescale design optimisation study. Water Res. 42 3930-3940.

BROWN N, JAMIESON H and BOTHA P (1998) Grow Restios. Kirstenbosch Gardening Series. National Botanical Institute, Cape Town.

CILLIERS SS and BREDENKAMP GJ (2000) Vegetation of road verges on an urbanisation gradient in Potchefstroom, South Africa.
Landscape. Urban Plann. 46 217-239.

CIRIA (2007) The SUDS Manual (C697). Classic House, London.

CoCT (CITY OF CAPE TOWN) (2009) Management of Urban Stormwater Impacts Policy (C 58/05/09). City of Cape Town Municipality, Cape Town.

DAVIS AP, SHOKOUHIAN M, SHARMA H and MINAMI C (2001) Laboratory study of biological retention for urban stormwater management. Water Environ. Res. 73 (1) 5-14.

DAVIS AP, SHOKOUHIAN M, SHARMA H, MINAMI C and WINOGRADOFF D (2003) Water quality improvement through bioretention: lead, copper, and zinc removal. Water Environ. Res. 75 (1) $73-82$.

DAVIS AP, SHOKOUHIAN M, SHARMA H and MINAMI C (2006) Water quality improvement through bioretention media: nitrogen and phosphorus removal. Water Environ. Res. 78 (3) 284-293.

DUNCAN G (1998) Grow Agapanthus. A Guide to the Species, Cultivation and Propagation of the Genus Agapanthus. National Botanical Institute, Cape Town.

ENVIRONMENT AGENCY (2003) Designs that hold waterSustainable drainage systems (SUDS) explained. Environment Agency, Bristol.

FLETCHER TD, ZINGER Y and DELETIC A (2007) Treatment efficiency of biofilters: results of a large scale biofilter column study. 13th International Rainwater Catchment Systems Conference and 5th International Water Sensitive Urban Design Conference, 21-23 August 2007, Sydney, Australia.

GHANI AAB, ZAKARIA NA, CHANG CK and AINAN A (2008) Sustainable Urban Drainage Systems (SUDS) - Malaysian experiences. Proc. 11th International Conference on Urban Drainage, 31 August - 5 September 2008, Edinburgh.

HATT BE, DELETIC A and FLETCHER TD (2007) Stormwater reuse: designing biofiltration systems for reliable treatment. Water Sci. Technol. 55 (4) 201-209.

HATT BE, DELETIC A and FLETCHER TD (2009) Hydrologic and pollutant removal performance of stormwater biofiltration systems at the field scale. J. Hydrol. 365 310-321.

HENDERSON C, GREENWAY M and PHILLIPS I (2007) Removal of dissolved nitrogen, phosphorus and carbon from stormwater by biofiltration mesocosms. Water Sci. Technol. 55 (4) 183-191.

HSIEH CH AN and D DAVIS AP (2005a) Evaluation and optimization of bioretention media for treatment of urban stormwater runoff. $J$. Environ. Eng. 131 (11) 1521-1531.

HSIEH CH and DAVIS AP (2005b) Multiple-event study of bioretention for treatment of urban storm water runoff. Water Sci. Technol. 51 (3-4) 177-181.

KNOX CITY COUNCIL (2002) Water Sensitive Urban Design Guidelines for the City of Know. KLM Development Consultants, Australia.

LIVINGSTON E (1992) Stormwater Management - A guide for Floridians. Florida Department of Environmental Regulation, Florida, USA.

MUSCOLO A, ROSARIA PANUCCIO M and SIDARI M (2003) Effects of salinity on growth, carbohydrate metabolism and nutritiveproperties of kikuyu grass (Pennisetum clandestinum Hochst). Plant Sci. 164 1103-1110.

POPOV VH, CORNISH PS AN and D SUN H (2006) Vegetated biofilters: The relative importance of infiltration and adsorption in reducing loads of water-soluble herbicides in agricultural runoff. Agric. Ecosyst. Environ. 114 351-359.

READ J, WEVILL T, FLETCHER TD and DELETIC A (2008) Variation among plant species in pollutant removal from stormwater in biofiltration systems. Water Res. 42 (4-5) 893-902.

REVITT DM, SHUTES RBE, JONES RH, FORSHAW $M$ and WINTER B (2004) The performance of vegetative treatment systems for highway runoff during dry and wet conditions. Sci. Total Environ. 334-335 261-270.

RUMBALL PJ (1991) The performance of several sub-tropical grasses in the Northland and Hill Pastures, New Zealand. J. Agric. 34 $375-382$.

SAVCHENKO T, WHITING P, SARKER SD and DINAN L (1997) Phytoecdysteroids in the genus Agapanthus (Alliaceae). Biochem. Syst. Ecol. 25 (7) 623-629. 
SOKAL RR and ROHLF FJ (1995) Biometry: the Principles and Practices of Statistics in Biological Research. W.H. Freeman and Co., San Francisco.

SAWS (SOUTH AFRICAN WEATHER SERVICE) (2011) Cape Town International Airport Climate Data: Annual Climate Statistics (1960-2000). South African Weather Service and 1stWeather.com. URL: http://clients.customweather.com/cgi-bin/1STWX/old/climate.cgi (Accessed 23 March 2011).
TROWSDALE SA and SIMCOCK R (2010) Urban stormwater treatment using bioretention. J. Hydrol. 397 (3-4) 167-174.

VILLARREAL EL, SEMADENI-DAVIES A and BENGTSSON A (2004) Inner city stormwater control using a combination of best management practices. Ecol. Eng. 22 279-298.

WOODS-BALLARD B, KELLAGHER R, MARTIN P, JEFFERIES C, BRAY R and SHAFFER P (2007) The SUDS Manual (CIRIA 697). Ciria, London. 